\title{
The Effect of Red Light on the Germination of a Brazilian Pteridophyte.
}

\author{
Áurea M. T. Colli and Sonia C. J. G. de A. Perez* \\ Departament of Botany, Federal University of São Carlos, Washington Luiz Highway, Km 235 Post-Box 676, \\ 13565-905, São Carlos, SP, Brazil.
}

\begin{abstract}
The effects of red light on the germination of spores of Cheilantes concolor Langsd \& Fisch were investigated in this study. The spores were spread in the Mohr (1956) nutritional solution after Dyer's modifications (1979). Three Petri dishes were used for each treatment, three slides per dish were made for each day of treatment, and one hundred spores per slide were counted. Germination of the spores in the dark was not observed. In relation to the photoperiods, the highest germination percentage and index values were obtained with the exposure of the spores to photoperiods of $8 \mathrm{~h}$, and the lowest values were obtained with their exposure to photoperiods of $2 \mathrm{~h}$. The phytochrome pigment acts in the germination of the spores through low fluency response. The highest germination percentage and index values were obtained with the highest irradiation while the lowest with the lowest irradiation.
\end{abstract}

Key words: germination, red light, far-red light, spores, pteridophyte.

\section{INTRODUCTION}

Cheilantes concolor Langsd \& Fisch is a pteridophyte species, native to tropical regions, being found in Brazil. Despite the great diversity of pteridophytes existent in tropical regions, only a few studies have been carried out on the effects of different factors which influence their germination (Tryon \& Tryon, 1982).

Light is often a constraint to spore or seed germination. It has been found that the majority of the pteridophyte species germinates in the presence of light, and its germination is controlled by phytochrome and cryptochrome pigments (Miller, 1968; Furuya, 1983; Kendrick \& Kronemberg, 1993). The role of the phytochrome pigment has been found in the germination of the following pteridophyte species : Thelypteris kunthii (Huckaby \& Raghavan, 1981); Cyathea delgadii (Randi \& Felippe, 1988); Polypodium latipes (Esteves \& Felippe, 1991); Thelypteris dentata (Colli \& Takaki, 1992); Thelypteris longifolia (Colli, 1996).

\footnotetext{
* Author for correspondence.
}

Temperature and its interaction with other environmental factors may modify the response of the pteridophyte spores to light (Towill, 1978; Mahlberg \& Yarus, 1977; Esteves \& Felippe, 1985; Ranal, 1983). In many pteridophytes species, such as Onoclea sensibilis (Towill, 1978) and Lygodium japonicum (Tomizawa et al., 1982), germination is induced by a short exposure to red light. However, some species need to be exposed to longer light periods for the germination process to occur (Colli, 1996; Esteves et a.l, 1985).

The aim of this study was to investigate the effect of red light on the germination of spores of $C$. concolor.

\section{MATERIALS AND METHODS}

The spores of $C$. concolor were collected in the campus of the Federal University of São Carlos, São Paulo State, Brazil, when the sori were closed and presented a dark brown color. The 
leaflets were collected and dried on a filter paper at ambient temperature for six days until they were completely dry. The spores on the filter paper were removed with a paintbrush and separated from the sporangium by filtering through a nylon screen.

Three Petri dishes containing $10 \mathrm{ml}$ of Mohr (1956) solution after Dyer's modification (1979) were used for each treatment. Three slides per dish were made per day of treatment, and one hundred spores per slide were counted. The Petri dishes were maintained in a incubator (B.O.D FANEM) at $25^{\circ} \mathrm{C}\left( \pm 1^{\circ} \mathrm{C}\right)$. Spores which presented protrusion of the rhizoid were considered germinated (Randi, 1987). The experiments carried out in the dark were obtained by wrapping the Petri dishes with a double aluminum foil and the readings were made under a green safelight (Felippe et al., 1985). The daily count of the germinated spores was recorded.

The following light sources were used: red light of $151.5 \mu \mathrm{W} . \mathrm{cm}^{-2}$, obtained with a $20 \mathrm{~W}$ daylight fluorescent lamp (General Electric) and a filter made of two pieces of red cellophane, and far-red light of $6.75 \mu \mathrm{W} . \mathrm{cm}^{-2}$, obtained with a $25 \mathrm{~W}$ incandescent bulb (General Electric) and a filter made of two pieces each of red and blue cellophane. The emission spectra of the red and far-red light were obtained with a L.I. 1800 (Licor.USA) spectroradiometer, and processed using the PL 1800 program (Figs. 1 and 2).

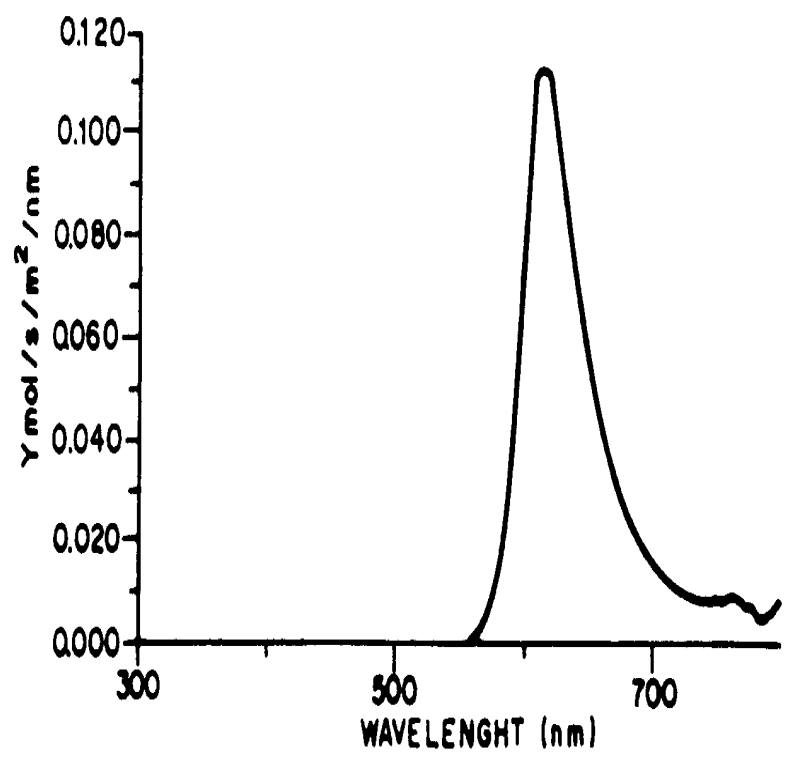

Fig. 1. The spectrum of red light used in the experiments with C. concolor.

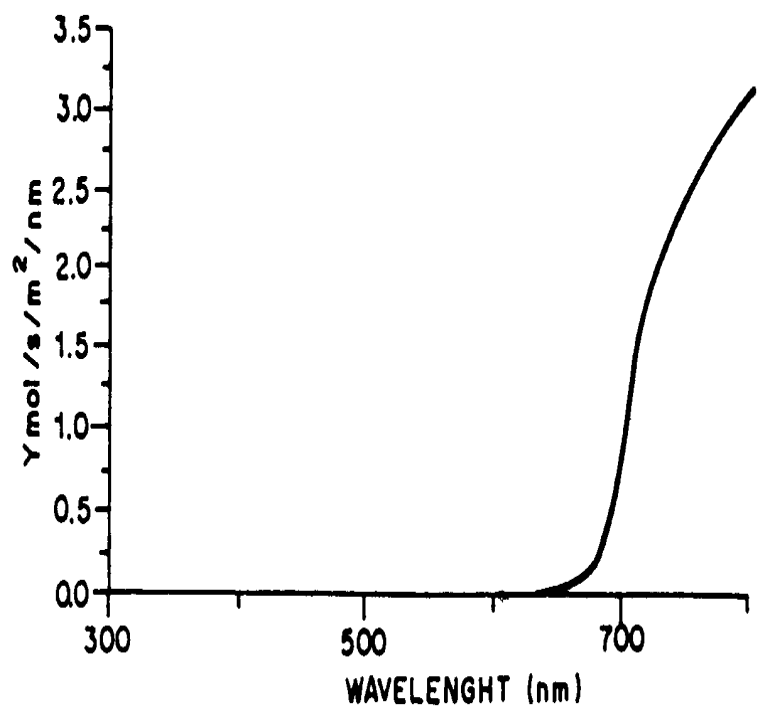

Fig. 2. The spectrum of far-red light used in the experiments with C. concolor.

The different irradiances were obtained by varying the distance between the Petri dishes and the light source. The irradiances of the red and far-red light were obtained according to Takaki (personal communication, cited in (Colli, 1996) and the germination index of the spores was calculated according the formula cited in Kendrick \& Frankland (1969) :

$\mathrm{G}=\mathrm{P} / \mathrm{t}$ where $: \mathrm{G}=$ Germination Index, $\mathrm{P}=$ Percentage maxim of germination, $t=$ Time necessary (hours) to occur the half of percentage maxim of germination.

The data were subjected to analysis of variance followed by Tuckey test. Statistical analysis was performed after arcsin $\sqrt{\%}$ transformation of the germination percentage data.

\section{RESULTS AND DISCUSSION}

The spores of $C$. concolor are photoblastic positive, since they germinate only in the presence of light. The effect of photoperiod on the germination of the spores of C. concolor are summarized in Fig. 3. It can be seen that the lowest germination percentage and index values were obtained with photoperiods of $2 \mathrm{~h}$ of red light and the highest with photoperiods of $8 \mathrm{~h}$ of red 
light. The exposure to photoperiods of $1 \mathrm{~h}$ completely suppressed germination.

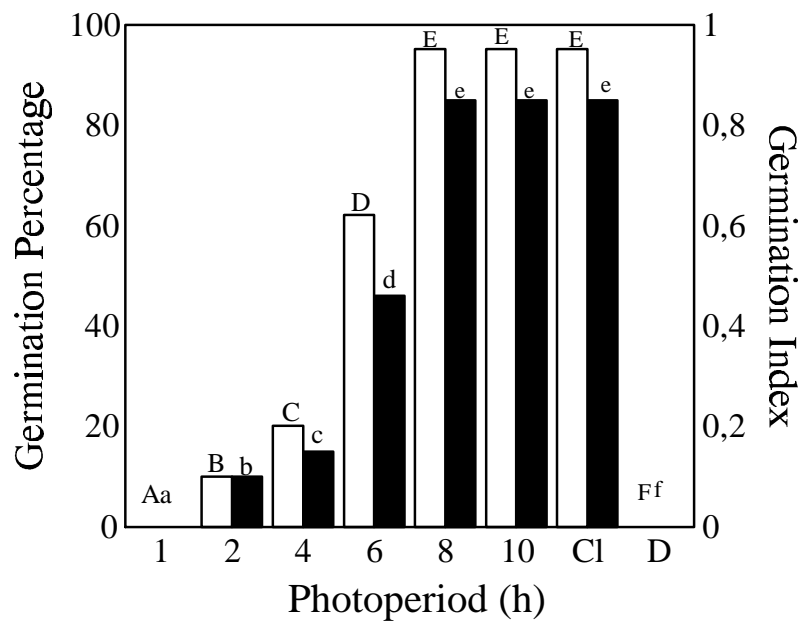

Fig. 3. The effect of different photoperiods of red light $\left(151.5 \mu \mathrm{W} . \mathrm{cm}^{-2}\right)$ on the germination of C. concolor. $\mathrm{Cl}=$ continuous light. $\mathrm{D}=$ dark. $\square$ Germination percentage Germination index. Values followed by the same letter are not significantly different at $5 \%$ level.

It has been found that the germination of the spores of various species of pteridophytes, such as Trichipteris corcovadensis and Schizaea pusilla is influenced by the different photoperiods of red light (Esteves et al., 1985; Guiragossian \& Koning, 1986).

One possible explanation for the effect of the photoperiodism on germination could be that with the interruption of the light regime by periods of dark, the pool of phytochrome in the active form (Fve) may not be sufficient to induce germination, since the reversal of Fve to Fv (inactive form) occurs in the dark. Some species, including $C$. concolor, probably need to be exposed to longer light periods so that a higher pool of Fve can be formed, which may induce germination.

The germination of spores of $C$. concolor induced by irradiation of $6 \mathrm{~h}$ of red light was inhibited by following exposure of the spores to far-red light for 15 or 30 minutes. This inhibition may have occurred because the period of irradiation used (15 or 30 minutes of far-red light) was sufficient for the active form of the phytochrome (Fve) to revert to the inactive form (Fv) (Fig.4).

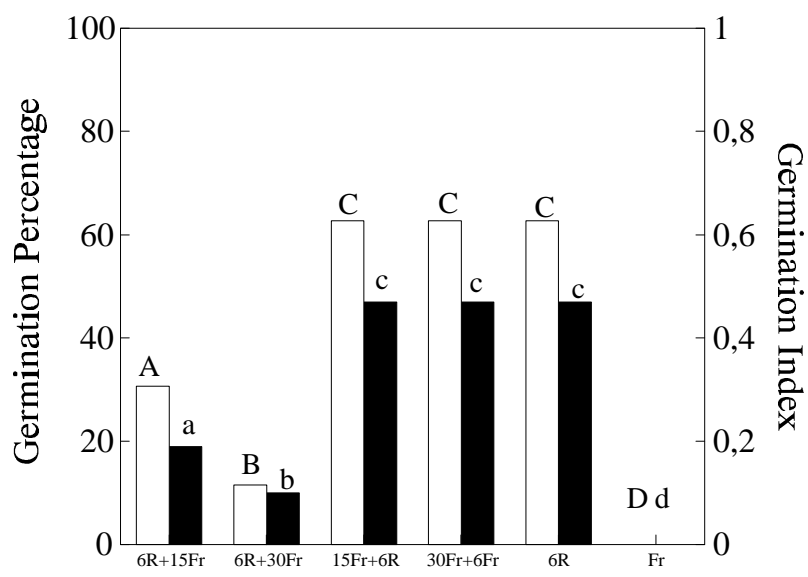

Fig. 4. The effect of 6 hours of red light $(151.5 \mu \mathrm{W}$. $\mathrm{cm}^{-2}$ ) followed by 15 or 30 minutes of far-red light $\left(6.75 \mu \mathrm{W} . \mathrm{cm}^{-2}\right)$, and 15 or 30 minutes of far-red light $\left(6.75 \mu \mathrm{W} . \mathrm{cm}^{-2}\right)$ followed by 6 hours of red light $\left(151.5 \mu \mathrm{W} . \mathrm{cm}^{-2}\right)$ on the germination of the spores of C. concolor. $6 \mathrm{R}+15 \mathrm{FR}=6$ hours of red light followed by 15 minutes of far-red light; $6 \mathrm{R}+30 \mathrm{FR}=6$ hours of red light followed by 30 minutes of far-red light; $15 \mathrm{FR}+6 \mathrm{R}=15$ minutes of far-red light followed by 6 hours of red light; $30 \mathrm{FR}+6 \mathrm{R}=30$ minutes of far-red light followed by 6 hours of red light. $6 \mathrm{R}=6$ hours of red light. $\mathrm{Fr}=$ continuous far-red light. $\square$ Germination percentage Germination index. Values followed by the same letter are not significantly different at 5\% level.

The germination induced by the red light and inhibited by the later exposure to far-red light and vice-versa is the classical response for the activity of the phytochrome (Kendrick \& Kronemberg, 1993). Since this response was observed in the spores of C. concolor, possibly the phytochrome might be the pigment responsible for the control of its germination.

Based on the germination behavior of $C$. concolor influenced by light, specifically the germination induced by red light and inhibited by the later exposure to far-red light and vice-versa, the inhibition of germination by continuous far-red light, and the need for prolonged periods of irradiation so that the induction of germination can occur, it can therefore be concluded that pytochrome acts in the germination of the spores of $C$. concolor through the low energy reaction. 
According to Kagawa \& Sugai (1991) and Souza \& Pereira (1994), red light induces the germination of the spores of Lygodium japonicum through an increase in the gibberellin content. In seeds of Impatiens wallerana the demand for a prolonged activity of Fve is related to its possible involvement with the biosynthesis of gibberellin. For the spores of $C$. concolor, phytochrome may be involved in the biosynthesis of gibberellin.

According to Kendrick \& Kronemberg (1993), continuous red light, which is absorbed by the inactive form of phytochrome $(\mathrm{Fv})$, establishes a photoequilibrium with a high proportion of the active form of phytochrome (0.86). Part of this pool could be destroyed if the light treatment was prolonged, but even so elevated proportions of Fve would occur, since the photoequilibrium is calculated based on the total amount of phytochrome. This could be a process occuring with the spores of $C$. concolor.

The highest germination percentage and index values of $C$. concolor spores were obtained with the use of the highest irradiances (Fig. 5), suggesting that at lower irradiances there was possibly a reversal from the active form (Fve) to the inactive form of phytochrome $(\mathrm{Fv})$, and as a consequence, the maintenance of the low proportion of Fve in relation to the total phytochrome.

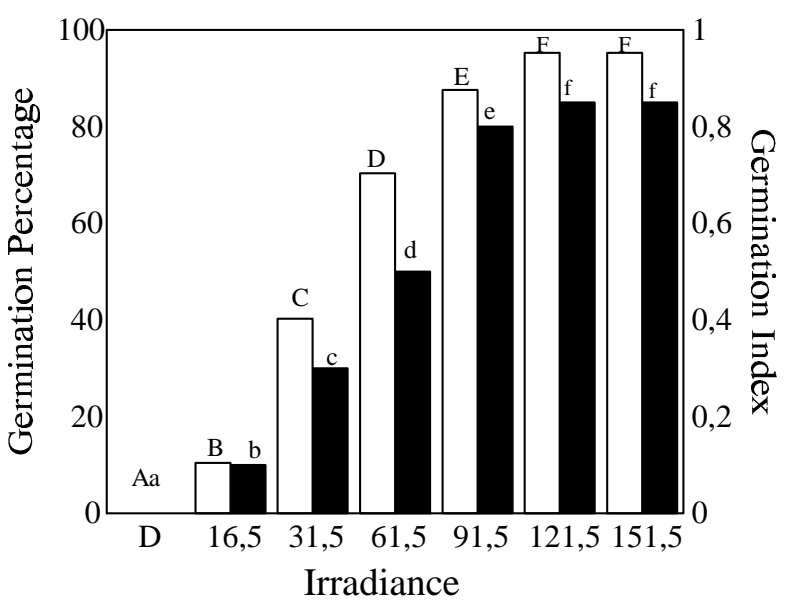

Fig. 5. The effect of different irradiances $\left(\mu \mathrm{W} . \mathrm{cm}^{-2}\right)$ of red light on the germination of $C$. concolor. $\mathrm{D}=$ dark. $\square$ Germination percentage $\square$ Germination index. Values followed by the same letter are not significantly different at $5 \%$ level.
The need for prolonged irradiances with continuous red light, or intermittent irradiances which contained a high proportion of red : far-red, as observed for $C$. concolor confered to this species an ecological advantage in detecting large clearings where incident light contained a high proportion of red : far-red, and there were no light limitations for photosynthesis and the survival of the seedling (Kendrick, 1976; Vasquez-Yanes \& Smith, 1982). This advantage might occur with $C$. concolor, which is natural to areas with large clearings.

\section{ACKNOWLEDGMENTS}

This study was supported by the Coordenação de Aperfeiçoamento do Ensino Superior - CAPES- as part of a Doctoral Thesis. The authoress thanks Dr. Massanori Takaki for the emission spectra of red and far-red light; Misha Klein and Dra. Inês Sechim for the translation.

\section{RESUMO}

Neste estudo foi verificado o efeito da luz vermelha na germinação dos esporos de Cheilantes concolor. Os esporos foram semeados na solução nutritiva de Mohr (1956) modificada por Dyer (1979). Foram utilizadas três placas de Petri por cada tratamento, e contadas três lâminas por placa e cem esporos por lâmina. A germinação dos esporos no escuro não foi observada. Com relação aos fotoperíodos os maiores valores de porcentagem e índice de germinação foram obtidos com a exposição dos esporos a fotoperíodos de $10 \mathrm{~h}$, e os menores valores com a sua exposição a fotoperíodos de $2 \mathrm{~h}$. $\mathrm{O}$ pigmento fitocromo atua na germinação dos esporos através da resposta de baixa fluência. Com relação a irradiância, os maiores valores de porcentagem e índice de germinação foram observados nas maiores irradiâncias e os menores nas menores irradiâncias.

\section{REFERENCES}

Colli, A.M.T.; Takaki, M. (1992). Estudo da germinação de esporo de Thelypteris dentata 
(Forssk) E. St. Jonhn. Arquivos de Biologia e Tecnologia, 35, 585-590.

Colli, A.M.T. (1996). Efeitos do alumínio, armazenamento, luz, $\mathrm{pH}$, reguladores de crescimento e temperatura na germinação da pteridófita Thelypteris longifolia (Desv.) R. Tryon. Doctoral Thesis, São Carlos : UFSCar.

Dyer, A. F. (1979). The culture of fern gametophytes for experimental investigation. In : The experimental biology, London : Academic Press, pp. 205-301.

Esteves, L. M.; Felippe, G. M. (1985). Fotossenssibilidade de esporos de pteridófitas dos cerrados. Revista Brasileira de Botânica, 8, 219-222.

Esteves, L.M.; Felippe, G.M.; Melhem, T.S. (1985). Germination and morphology of spores of Trichipteris corcovadensis. American Fern Journal, 75, 92-102.

Esteves, L.M.; Felippe, G. M. (1991). Efeito da luz na germinação dos esporos de Polypodium latipes Langsd \& Fisch. Hoehnea, 18, 53-59.

Felippe, G.M.; Válio, I.F.M.; Pereira, M.F.A.; Sharif, R.R.; Vieira, S.R. (1985). Fotomorfogênese e germinação. In: Fisiologia do Desenvolvimento Vegetal, Campinas, Editora da UNICAMP, pp. 9 - 15.

Furuya, M. (1983). Photomorphogenesis in plants. In : Photomorphogenesis. Berlim : Ed. Shropshere, W. and Mohr, H. P., pp. 559-600 (Encyclopedia of Plant Physiology) N.S. v. 16A, Berlim.

Guiragossian, H.A.; Koning, R.E. (1986). Induction of spore germination in Schizaea pusilla (Schizaceae). American Journal of Botany, 73, 1588-1594.

Huckaby, C. S.; Raghavan, V (1981). Photocontrol of spore germination in the fern Thelypteris kunthii. Physiology Plantarum, 51, 19-22.

Kagawa, T.; Sugai, M. (1991). Involvement of gibberellic-acid in phytochrome mediated spore germination of the fern Lygodium japonicum. Journal of Plant Physiology, 138, 299-303.

Kendrick, R.E. (1976). Photocontrol of seed germination. Scientific Program Oxford, 63, 347-367.

Kendrick, R.E.; Frankland, B. (1969). Photocontrol of germination in Amaranthus caudatus. Planta, 85, 326-339.
Kendrick, R.E.; Kronemberg, G.H.M. (1993). The physiology of action. In : Photomorphogenesis in Plants, Netherlands: Kluwer Academic Publishers, pp. 211-226.

Mahlberg, P. G.; Yarus, S. (1977). Effects of light, $\mathrm{pH}$, temperature and crowding on megaspore germination and sporophyte formation in Marsilea. Journal of Experimental Botany, 2, 129-137.

Miller, J.H. (1968). Fern gametophytes as experimental material. The Botanical Review, 34, 362-426.

Mohr, H. (1956). Die Abhangigkeit des protonemawachstums un der protonemapolaritat bei farnen vom licht. Planta, 47, 127-158.

Ranal, M.A. (1983). Efeito da temperatura e da intensidade luminosa no desenvolvimento de gametófitos de pteridófitas. Master Thesis, Rio Claro : UNESP.

Randi, A. M. (1987). Aspectos fotomorfogênicos, bioquímicos e citoquímicos durante a germinação de esporos de Cyathea delgadii Sternb. Doctoral Thesis, Campinas: UNICAMP.

Randi, A. M.; Felippe, G. M. (1988). Effect of red light and far-red light on the germination of spores of Cyathea delgadii. Revista Brasileira de Botânica, 11, 41-45.

Souza, R. P.; Pereira, M. F. A. (1994). Photocontrol of seed germination in Impatiens wallerana Hook f. Plant Growth Regulation, 14, 249-256.

Towill, L. (1978). Temperature and photocontrol of Onoclea spore germination. Plant Physiology, 62, 116-119.

Tomizawa, K.; Manabe, K; Sugai, M. (1982). Changes in phytochrome content during inhibition in spores of the fern Lygodium japonicum. Plant \& Cell Physiology, 23, 1305-1308.

Tryon, R.M.; Tryon, A.F. (1982). Ferns and allied plants. New York : Spring -Verlag.

Vásquez-Yanes, C.; Smith, H. (1982). Phytochrome control of seed germination in the tropical rain forest pioneer trees Cecropia obtusifolium and Piper auritum and its ecological significance. New Phytologist, 92, 477-485.
Received: March 18, 1998; Revised: June 30, 1998; Accepted: August 05, 1998. 